\title{
Planowanie rozwoju usługowego produktu turystyki wędkarskiej w oparciu o posiadane walory endogeniczne. Przykład powiatu szczecineckiego
}

\section{Planning the Fishing Service Tourism Product Development Based on Endogenous Values. Example of the Szczecinek County (Poland)}

\begin{abstract}
Streszczenie: Artykuł zawiera przegląd zagadnień dotyczących planowania rozwoju lokalnej przestrzeni usługowej, ze szczególnym uwzględnieniem implementacji usług turystycznych oraz lokalnego turystycznego produktu wędkarskiego w oparciu o posiadane lokalne zasoby endogeniczne, w szczególności wodne, głównie w postaci jezior i rzek. Badaniem objęto obszar powiatu szczecineckiego znajdującego się w województwie zachodniopomorskim. W artykule zastosowano następujące metody badawcze: ankietowa, opisowa, zogniskowane wywiady grupowe oraz przeprowadzono analizę dokumentów strategicznych i przygotowano analizę SWOT. W artykule wskazano istotne elementy, które wyróżniają powiat szczecinecki jako obszar wędkarski, przeprowadzono inwentaryzację zasobów wodnych oraz wskazano najważniejsze bariery rozwoju tego typu produktów usługowych. Badania prowadzone w powiecie szczecineckim wykazały, że jest to obszar predestynowany do rozwoju tego typu produktów turystycznych, jednakże wymagane jest wyraźne zaangażowanie instytucjonalne władz powiatowych, poszczególnych gmin oraz organizacji powiatowych. Dzięki posiadanym zasobom endogenicznym powiaty tego typu mogą z powodzeniem realizować funkcję usługową w dziedzinie turystyki. Badania przeprowadzone na potrzeby niniejszego artykułu są uzupełnieniem podobnych badań prowadzonych w związku z rozwojem turystyki w innych gminach i powiatach województwa zachodniopomorskiego.
\end{abstract}

Abstract: The article provides an overview of issues related to planning the development of local service space, with particular emphasis on the implementation of tourist services and the local tourist fishing product based on local endogenous resources, in particular water, mainly in the form of lakes and rivers. The study covered the area of the Szczecinek County located in the Zachodniopomorskie Voivodeship. The following research methods were used in the article: survey, descriptive, focused group interviews, strategic documents analysis and SWOT analysis. The article indicates important elements that distinguish the Szczecinek County as a fishing area, inventory of water resources was carried out and the most important barriers to the development of this type of service products were indicated. Research conducted in the Szczecinek County has shown that it is an area predestined for the development of this type of tourist products, however, a clear institutional commitment of county authorities, individual communes and county organisations is required. Thanks to their endogenous resources, counties of this type can successfully perform service functions in the field of tourism. Research carried out for the purposes of this article is a supplement to similar 
research conducted in connection with the development of tourism in other communes and counties of the Zachodniopomorskie Voivodeship.

Słowa kluczowe: powiat; powiat szczecinecki; produkt wędkarski; rozwój lokalny; usługi turystyczne Keywords: county; fishing product; local development; Szczecinek County; tourist services

Otrzymano: 23 grudnia 2019

Received: 23 December 2019

Zaakceptowano: 26 kwietnia 2020

Accepted: 26 April 2020

Sugerowana cytacja / Suggested citation:

Szostak, D. (2020). Planowanie rozwoju usługowego produktu turystyki wędkarskiej w oparciu o posiadane walory endogeniczne. Przykład powiatu szczecineckiego. Prace Komisji Geografii Przemysłu Polskiego Towarzystwa Geograficznego, 34(3), 22-35. doi: 10.24917/20801653.343.2

\section{WSTĘP}

Artykuł zawiera przegląd zagadnień dotyczących planowania rozwoju lokalnej przestrzeni usługowej, ze szczególnym uwzględnieniem implementacji usług turystycznych do lokalnej przestrzeni oraz analizę rozwoju lokalnego turystycznego produktu wędkarskiego w oparciu o zlokalizowane w danej przestrzeni badawczej lokalne zasoby endogeniczne, w szczególności wodne, głównie w postaci jezior i rzek. Badanie zostało przeprowadzone w 2019 roku. Badaniem objęto obszar powiatu szczecineckiego znajdującego się w województwie zachodniopomorskim. W artykule zastosowano następujące metody badawcze: ankietową, opisową, zogniskowane wywiady grupowe, przeprowadzono też analizę dokumentów strategicznych oraz przygotowano analizę SWOT.

W artykule wskazano istotne elementy, które wyróżniają powiat szczecinecki jako obszar wędkarski, przeprowadzono inwentaryzację zasobów wodnych i wskazano najważniejsze bariery rozwoju tego typu produktów usługowych. Badania prowadzone w powiecie szczecineckim wykazały, że jest to obszar predestynowany do rozwoju tego typu produktów turystycznych, jednakże wymagane jest wyraźne zaangażowanie instytucjonalne władz powiatowych, poszczególnych gmin oraz organizacji powiatowych. Dzięki posiadanym zasobom endogenicznym powiaty tego typu mogą z powodzeniem realizować funkcję usługową w dziedzinie turystyki. Badania przeprowadzone na potrzeby niniejszego artykułu są uzupełnieniem podobnych badań prowadzonych w związku z rozwojem turystyki w innych gminach i powiatach województwa zachodniopomorskiego.

Rozwój turystycznej funkcji usługowej danego obszaru, np. gminy czy powiatu, najczęściej opiera się na posiadanych zasobach endogenicznych. Stanowią one w wielu przypadkach podstawę do opracowania i wdrożenia lokalnej strategii turystycznej lub niekiedy, o ile zachodzi taka potrzeba rozwojowa, strategii rozwoju konkretnego produktu turystycznego, zwłaszcza w przypadku, gdy walory endogeniczne są dominujące, a dana forma turystyki ma wyraźne przesłanki pozytywnej jej implementacji (Szostak, 2019).

Jak pokazuje praktyka, w wielu gminach województwa zachodniopomorskiego - i nie tylko - turystyczna funkcja usługowa (w wymiarze gospodarczym i komercyjnym najczęściej realizowana poprzez wykorzystanie posiadanych zasobów naturalnych lub antropogenicznych) może mieć i najczęściej ma charakter wiodący lub też 
uzupełniający inne funkcje gospodarcze realizowane na danym obszarze (Sidorkiewicz, 2009). Rozwój turystycznej funkcji usługowej danego obszaru (najczęściej gminy lub powiatu) wynika przede wszystkim z wykorzystania do celów gospodarczych posiadanego potencjału endogenicznego, zarówno w aspekcie historycznym (np. na podstawie kontynuacji rozwoju dotychczasowej specyfiki turystycznej danego obszaru), jak i przyszłościowym (najczęściej na podstawie rozwoju i implementacji nowych kierunków działania i nowych aktywności). Wielokrotnie bywa tak, że poprzednie funkcje nadal są realizowane, ale dana struktura gospodarcza jest już optymalnie ukształtowana i albo nie podlega potrzebom wdrażania istotnych przemian lub wymagana jest niewielka korekta. Czasami jest jednak tak, że lokalne władze samorządowe dochodzą do wniosku, że niezbędne jest znalezienie nowych kierunków rozwoju, które jeszcze lepiej przyczyniłyby się do wykorzystania posiadanych zasobów endogenicznych (Głąbiński, Duda, Szostak, 2017).

W związku z powyższym obszarem do badań teoretycznych, opisowych, inwentaryzacyjnych oraz empirycznych wybrano powiat szczecinecki (województwo zachodniopomorskie), a celem artykułu jest analiza problematyki planowania rozwoju nowego produktu turystycznego, w szczególności wędkarskiego, na danym obszarze już mającym określony potencjał turystyczny, w oparciu o posiadane zasoby wodne, głównie rzeczne i jeziorne. Hipoteza badawcza brzmi z kolei następująco: posiadane przez analizowany powiat i jego poszczególne gminy wodne zasoby endogeniczne mogą stanowić podstawę do tworzenia jeszcze bardziej specjalistycznych produktów turystycznych i kreowania na ich podstawie lokalnej strategii rozwoju.

\section{TURYSTYKA JAKO NARZĘDZIE ROZWOJU GOSPODARCZEGO I USŁUGOWEGO JEDNOSTEK SAMORZĄDOWYCH}

W coraz większej liczbie gmin i powiatów turystyka i związana z tym w ujęciu praktycznym gospodarka turystyczna stanowi ważną część podażowej przestrzeni gospodarczej, w tym usługowej. Turystyka pełni funkcję stymulującą lokalny rozwój i często dotyczy jednostek samorządu terytorialnego, które postrzegają usługi turystyczne jako czynnik pobudzający i ukierunkowujący lokalny rozwój społeczno-gospodarczy. Zdarza się, że obszary te nie były wcześniej traktowane jako destynacje turystyczne, ale dzięki pojawieniu się nowych turystycznych funkcji stymulujących lokalną gospodarkę stają się stopniowo atrakcyjne dla ruchu turystycznego, potencjalnych turystów i odwiedzających, a niekiedy stają się obszarami (destynacjami) alternatywnymi dla turystyki masowej (Grabowska, 2016).

Dla lokalnych władz samorządowych rozwój turystyki i realizacja związanych z nią inwestycji turystycznych sprzyjają również działaniom dywersyfikującym lokalną gospodarkę. Działania takie powinny być poprzedzone wnikliwą inwentaryzacją posiadanych zasobów naturalnych, kulturowych czy też ogólnie turystycznych (Gołembski, 2002). Inwentaryzacja taka pozwoli przeprowadzić następnie analizę SWOT owego obszaru pod kątem rozwoju lokalnej gospodarki turystycznej i pomoże wskazać kierunki dalszego rozwoju turystycznego danego regionu. Niewłaściwe byłoby inicjowanie działań proturystycznych, a w dalszej kolejności kreowanie na bazie posiadanych zasobów lokalnych produktów turystycznych, które nie wyjdą naprzeciw potrzebom turystów. Ze strony władz samorządowych pożądanym działaniem jest również zachęcanie lokalnych przedsiębiorców, a także społeczności do aktywnego angażowania się w działania 
prorozwojowe i proturystyczne. Brak wyraźnych chęci lub niezrozumienie problemu ze strony lokalnej przedsiębiorczości może przyczynić się do poniesienia porażki w obszarze podejmowanych działań proturystycznych w danej gminie czy powiecie. Działania proturystyczne powinny stanowić istotny element długofalowej strategii regionalnego i lokalnego rozwoju (Głąbiński, Szostak, Zalewski, 2016).

Zależność lokalnych jednostek samorządu terytorialnego (głównie gmin, ale też powiatów) od turystyki i od rozwoju usługowej gospodarki turystycznej jest tym większa, im wyższy jest ich poziom atrakcyjności turystycznej. Na atrakcyjność turystyczną takiego obszaru składa się przede wszystkim, występowanie walorów naturalnych oraz jakość i pojemność infrastruktury turystycznej i paraturystycznej. W przypadku wielu gmin i powiatów turystyka staje się coraz częściej dominującą dziedziną lokalnej gospodarki, a poprzez to staje się poważnym akceleratorem rozwoju lokalnego.

Ukierunkowany rozwój danej przestrzeni samorządowej w oparciu o posiadane zasoby endogeniczne, głównie przyrodnicze i antropogeniczne, powinien polegać przede wszystkim na kreowaniu niezbędnej infrastruktury społeczno-gospodarczej oraz podejmowaniu działań w kierunku zagospodarowania posiadanych zasobów endogenicznych (np. przyrodniczych), jak i wykorzystania kompetencji samych mieszkańców (np. proprzedsiębiorczych).

Władze samorządowe nie mają za zadanie świadczyć konkretnych usług komercyjnych, w tym turystycznych, ale stwarzają lokalnym podmiotom prywatnym i mieszkańcom możliwości świadczenia, najczęściej w postaci komercyjnej, określonych usług, które przyczyniają się do kreowania miejsc pracy, przynosząc dochody świadczącym owe usługi oraz warunkują rozwój innych usług, gdzie realizowane usługi na zasadzie komplementarności uzupełniają się nawzajem, stanowiąc jeden produkt końcowy.

Do podstawowych korzyści gospodarczych związanych z rozwojem lokalnej turystyki należy zaliczyć przede wszystkim:

- napływ środków pieniężnych (w tym dewiz);

- wzrost konkurencyjności lokalnej gospodarki;

- rozwój działalności inwestycyjnej w regionie;

- lepsze wykorzystanie istniejącej lokalnej infrastruktury turystycznej i paraturystycznej;

- lepsze wykorzystanie istniejących lokalnych walorów;

- poprawę jakości funkcjonowania lokalnej infrastruktury komunalnej;

- tworzenie dodatkowych miejsc pracy (Panasiuk, 2006).

Władze samorządowe lokalnego szczebla są głównymi podmiotami odpowiedzialnymi za rozwój lokalny, a w przypadku gdy turystyka odgrywa stymulacyjną rolę rozwojową, za kreowanie lokalnej polityki turystycznej. Takie podejście wynika przede wszystkim z faktu, że turystyka staje się w wielu lokalnych obszarach sposobem na kreowanie nowych miejsc pracy, a usługi turystyczne stają się produktami „eksportowymi” lokalnych gospodarek (Kaczmarek, Stasiak, Włodarczyk, 2005). Dlatego też w gminach i powiatach turystycznych szczególne miejsce w zaspokajaniu potrzeb turystów zajmują podmioty prowadzące działalność gospodarczą w turystyce. Odpowiednie oddziaływanie ze strony władz lokalnych na postępowanie tychże podmiotów pozwala na realizację poszczególnych celów zawartych w lokalnych strategiach rozwoju. Oddziaływanie to może polegać na zachęcaniu do podejmowania aktywności gospodarczej w obszarze turystyki, w tym na wyborze określonego rodzaju działalności gospodarczej w turystyce, podejmowaniu określonych przedsięwzięć inwestycyjnych 
w infrastrukturę turystyczną, tworzeniu dalszych miejsc pracy w branży turystycznej i współudziale w tworzeniu i promocji lokalnego produktu turystycznego (Rapacz, Jaremen, 2009).

Jednostki samorządu terytorialnego mogą podejmować szereg działań prorozwojowych w obszarze gospodarki turystycznej, takich jak:

- promowanie usługowej oferty turystycznej danego obszaru,

- zagospodarowywanie posiadanych zasobów poprzez budowę niezbędnej infrastruktury, która warunkuje eksploatację tychże walorów oraz tworzenie nowych produktów,

- modernizacja już funkcjonującej w gminie czy powiecie infrastruktury społeczno-gospodarczej,

- pozyskiwanie środków zewnętrznych niezbędnych do powstania konkretnego rodzaju infrastruktury, zwłaszcza wysokokosztowej,

- planowanie rozwoju danej przestrzeni m.in. poprzez opracowywanie i wdrażanie lokalnych strategii rozwoju, w tym strategii rozwoju turystyki, opracowywanie koncepcji i planów rozwoju nowych produktów turystycznych,

- inicjowanie działań zwiększających lokalną przedsiębiorczość i inicjatywę prousługową mieszkańców itp.

\section{CHARAKTERYSTYKA PRODUKTU TURYSTYKI WĘDKARSKIEJ}

Turystyka wędkarska jest określana jako jeden z rodzajów turystyki aktywnej, zwłaszcza turystyki kwalifikowanej. Rozumiana jest jako turystyczne wyjazdy poza swoje miejsce zamieszkania związane z aktywnym spędzaniem czasu nad wodą (jeziorami i rzekami), a przede wszystkim $\mathrm{z}$ amatorskim łowieniem ryb na wędkę za pomocą ściśle określonego przepisami sprzętu, odpowiadające ustalonym w środowisku zwyczajom. Do praktycznych działań i aktywności związanych z uprawianiem turystyki wędkarskiej na danym obszarze należy:

- organizowanie wędkarstwa jako racjonalnej formy wypoczynku i rekreacji,

- tworzenie dogodnych warunków do uprawiania wędkarstwa,

- rozwój umiłowania przyrody i krzewienia znajomości zasad gospodarki wędkarsko-rybackiej (Kaganek, 2015).

Wędkarstwo to sposób na czynny i aktywny wypoczynek, a zarazem okazja do bliskiego kontaktu z przyrodą, zwłaszcza tą o charakterze wodnym. Wędkarze są to najczęściej ludzie (turyści) poszukujący ciszy i spokoju w otoczeniu cieków i zbiorników wodnych. Łowienie ryb połączone z wyjazdami i wypoczynkiem na łonie natury jest aktywną formą ruchu turystycznego. Współcześnie wędkarstwo funkcjonuje jako niezależny produkt turystyki specjalistycznej oraz stanowi doskonałe uzupełnienie oferty wypoczynkowo-rekreacyjnej na danym obszarze (w szczególności dla terenów pojeziernych i nadmorskich). Ocena atrakcyjności turystycznej, w tym wędkarskiej, cieków wodnych i akwenów opiera się na wartości środowiska przyrodniczego, przy założeniu, że gospodarka wędkarska może być prowadzona na większości wód oraz pod warunkiem przestrzegania obowiązujących w tym zakresie przepisów. Jedną z form współczesnego wędkarstwa jest wędkarstwo amatorskie w postaci łowienia ryb przy pomocy wędki, w sposób zgodny z lokalnymi przepisami. Każdy wędkarz musi przestrzegać wymiarów i okresów ochronnych ryb. Wędkarstwo dzieli się współcześnie na wędkarstwo sportowe i popularne. Wyróżnia się również konkretne 
rodzaje wędkarstwa, jak spławikowe, gruntowe, muchowe, podlodowe, morskie, rzutowe i spinningowe.

Wędkarstwo jako obszarowy produkt turystyczny obejmuje wiele różnych elementów składowych, a przede wszystkim:

- zasobne w ryby rzeki i zbiorniki wodne; akweny wodne predestynowane do uprawiania wędkarstwa muszą być zasobne w ryby pod względem ilości i jakości;

- korzystanie ze specjalistycznego sprzętu wędkarskiego;

- infrastrukturę techniczną, jak pomosty i miejsca przystosowane do wędkowania; są to przede wszystkim jeziora z odpowiednim zapleczem dla wędkarzy (przede wszystkim pomosty dla wędkarzy, wypożyczalnia łódek);

- aktualną informację, gdzie można łowić (uprawiać wędkarstwo) na danym obszarze i jaki jest rybostan;

- usługi noclegowe oraz żywieniowe; przede wszystkim w pobliżu wędkarskich akwenów wodnych;

- usługi transportowe oraz możliwość dojazdu i parkowania w miejscu docelowym wędkowania;

- serwis wędkarski, w tym m.in. usługi i działalność sklepów wędkarskich, przewodników i instruktorów wędkarskich;

- organizację imprez wędkarstwa sportowego i rekreacyjnego, zwłaszcza zawodów, eventów, spotkań integracyjnych;

- możliwość formalnego i nieformalnego zrzeszania się w organizacjach wędkarskich lub turystyczno-wędkarskich.

Wędkarstwo to coś więcej niż wędkowanie, czyli sama w sobie czynność łowienia ryb. Polska perspektywa funkcjonowania wędkarstwa i turystyki wędkarskiej jest dość specyficzna. W Polsce wędkowanie jako formę rekreacji uprawia zaledwie co czterdziesty obywatel. Całkiem inaczej wygląda to w krajach wysoko uprzemysłowionych, gdzie problemy cywilizacyjne oddziałują najsilniej. We Francji łowi co dziesiąty mieszkaniec, w Holandii i USA co piąty, w Szwecji co czwarty; wliczając niemowlęta, starców oraz kobiety. Nic też dziwnego, że na potrzeby tej rzeszy pracuje rozwinięty przemysł okołowędkarski. Zasadność rozwoju i inwestowania w wędkarstwo widzi również lokalna społeczność i władza. To jeden z gospodarczych aspektów wędkarstwa. Ta rzesza nad wodami nie pozostaje też bez wpływu na ich stan. Skąd kolejne konsekwencje gospodarcze, na styku z biologicznymi. Dalej: żaden rząd nie zostawia takiego ruchu samopas. Przynajmniej tworzy regulacje prawne. Czasem też - urządza sobie dodatkowe źródło dochodów, np. w postaci aktywizowania turystyki wędkarskiej i kreowania odpowiedniej przestrzeni predestynowanej do rozwoju infrastruktury i produktów wędkarskich.

„Turysta wędkarski to więc osoba, która swój urlop poświęca na wypoczynku nad wodą, wędkując. Oczywiście często wiąże się to z rodzinnymi wypadami, gdzie mąż łowi ryby, żona zaś z dziećmi relaksuje się w inny sposób (łowić też rzecz jasna mogą)" (Spławik i grunt, 2019).

Podsumowując, należy stwierdzić, że połowy ryb w wodach śródlądowych, przede wszystkim na wodach stojących i płynących, podzielić należy na profesjonalne - dokonywane przez uprawnionych do tego rybaków (rybołówstwo komercyjne) oraz amatorskie - prowadzone głownie przez wędkarzy (rybołówstwo rekreacyjne).

O ile w pierwszym przypadku głównymi celami działalności wędkarskiej i rybackiej są cele ekonomiczne (zysk) i ekologiczne (zachowanie ekosystemu rybnego), o tyle w przypadku wędkarskich połowów amatorskich głównym powodem wędkowania jest 
przede wszystkim odpoczynek, rekreacja i rywalizacja sportowa oraz chęć pozyskania pożywienia. Należy jednak dodać, że zysk dla wszystkich beneficjentów rozwoju gospodarki wędkarskiej, w tym turystyczno-usługowej, w dłuższym okresie jest możliwy tylko w dobrze funkcjonującym ekosystemie.

Połowy wędkarskie dokonywane są na niemal 100\% wód śródlądowych w Polsce, co pokazuje, że do rozwoju produktu turystyki wędkarskiej są predestynowane wszystkie te obszary, które posiadają na swoim terenie jeziora i rzeki.

\section{CHARAKTERYSTYKA WODNEGO POTENCJAŁU ENDOGENICZNEGO POWIATU SZCZECINECKIEGO}

Powiat szczecinecki to powiat leżący w północno-zachodniej Polsce, w województwie zachodniopomorskim, w jego środkowo-wschodniej części. Został utworzony w 1999 roku $\mathrm{w}$ ramach reformy administracyjnej. Jego siedzibą jest miasto Szczecinek. Jest to drugi pod względem powierzchni powiat w województwie zachodniopomorskim. W skład powiatu wchodzą następujące gminy (GUS, 2019):

- miejska Szczecinek (40,8 tys. mieszkańców),

- miejsko-wiejskie: Barwice (9 tys. mieszkańców), Biały Bór (5,4 tys. mieszkańców), Borne Sulinowo (9,8 tys. mieszkańców),

- wiejskie: Grzmiąca (5,1 tys. mieszkańców), Szczecinek (9,5 tys. mieszkańców).

$\mathrm{Na}$ terenie powiatu obecny jest także przemysł. Jednakże powiat szczecinecki jest uznawany przez specjalistów za jeden z najatrakcyjniejszych regionów Pomorza Zachodniego. Dla wielu turystów jest to doskonały obszar predestynowany do uprawiania różnych form turystyki aktywnej, kwalifikowanej i specjalistycznej, a zwłaszcza opartych na zasobach wodnych, w szczególności wędkarstwa (Skowyrski, 2010).

Powiat szczecinecki leży na pograniczu Pojezierza Szczecineckiego i Pojezierza Drawskiego i często nazywany jest „skarbem ukrytym wśród jezior”. Silnie urozmaicony krajobraz, liczne jeziora i gęsta sieć rzeczna to najważniejsze elementy wyróżniające powiat szczecinecki na tle pozostałych regionów Pomorza Zachodniego. Największym obszarem ochrony przyrody w powiecie szczecineckim jest Drawski Park Krajobrazowy, który obejmuje swoimi granicami rezerwaty, pomniki przyrody oraz liczne gatunki roślin i zwierząt. Teren parku i otuliny położony jest we wschodniej i południowo-wschodniej części powiatu na terenach gmin Borne Sulinowo i Barwice. Ponadto na terenie powiatu ustanowiono pięć rezerwatów przyrody, około 180 pomników przyrody (drzewa, grupy drzew, aleje i głazy narzutowe), cztery obszary chronionego krajobrazu i użytki ekologiczne, o łącznej powierzchni 336,56 ha. Powierzchnię powiatu w około 45\% pokrywają użytki leśne. Ogólny stan zdrowotny lasów powiatu określany jest jako dobry, do czego przyczynia się małe nasilenie przemysłu na tym terenie (Duda, Duda, Śledziński, 2014).

Na terenie powiatu szczecineckiego zinwentaryzowane zostały 92 jeziora, w tym 83 jeziora, dla których marszałek województwa zachodniopomorskiego wykonuje prawa właścicielskie w imieniu Skarbu Państwa. Wśród tych jezior znajdują się te, które posiadają duży potencjał rozwojowy z punktu widzenia turystyki wędkarskiej, a mianowicie: Jeleń (Borne Sulinowo), Radacz (Borne Sulinowo), Trzesiecko (miasto Szczecinek), Wielimie (Szczecinek), Wierzchowo (Szczecinek). Dla pozostałych dziewięciu jezior prawa właścicielskie w imieniu Skarbu Państwa wykonuje dyrektor Regionalnego Zarządu Gospodarki Wodnej w Poznaniu. Największym jeziorem z tej grupy 
o największym potencjale turystycznym jest jezioro Pile (Borne Sulinowo). Starosta szczecinecki wykonuje prawa właścicielskie w imieniu Skarbu Państwa dla 16 jezior.

Na terenie powiatu znajduje się również wiele rzek, z których największe znaczenie dla turystyki ma rzeka Parsęta (płynąca do Morza Bałtyckiego). W jej zlewni znajdują się kolejne 23 rzeki. Z kolei do zlewni rzeki Gwdy należy 45 rzek powiatowych.

Podsumowując, można stwierdzić, że na terenie powiatu szczecineckiego dla rozwoju produktu turystyki wędkarskiej szczególne znaczenie mają cztery następujące jeziora, a mianowicie: Wierzchowo, Wielimie, Trzesiecko oraz jezioro Pile. Ważne są również rzeki, które wraz z jeziorami wykorzystane zostały do stworzenia sieci szlaków kajakowych: Gwda - 44,9 km, Pętla Szczecinecka - 61,4 km, Nizica - 10,4km, Górna Płytnica - 11,3 km oraz Piława - 37,3 km. Wodne zasoby endogeniczne powiatu szczecineckiego wykorzystywane są również do tworzenia licznych szlaków rowerowych, pieszych oraz konnych. Wielość zasobów wodnych powoduje, że powiat szczecinecki położony jest na terenie trzech mezoregionów: Pojezierza Drawskiego, Pojezierza Szczecineckiego i Doliny Gwdy. W bardzo małym stopniu teren powiatu szczecineckiego obejmują mezoregiony Równiny Wałeckiej oraz Pojezierza Bytowskiego.

\section{ANALIZA INSTYTUCJONALNEGO POTENCJAŁU TURYSTYCZNEGO POWIATU SZCZECINECKIEGO}

Analiza dokumentów oraz działań strategicznych pięciu gmin (Biały Bór, Barwice, Borne Sulinowo, Grzmiąca, Szczecinek) i powiatu szczecineckiego oraz Lokalnej Grupy Działania „Pojezierze Razem” w zakresie turystyki, w tym turystyki wędkarskiej i turystyki opartej na zasobach wodnych (akweny stojące i płynące, jeziora i rzeki) wykazała brak w ogóle dokumentu nadrzędnego odnoszącego się swoją treścią do zagadnień wyłącznie z zakresu turystyki wodnej i wędkarskiej. Jedna gmina (Biały Bór) posiada aktualną strategię rozwoju turystyki (do 2022 roku). Gmina ta w szczególności wskazuje na podjęcie działań skierowanych na wydłużenie sezonu turystycznego, w tym wskazano na rozwój turystyki rybackiej i wędkarskiej, organizację zawodów wędkarskich, a także tworzenie łowisk wędkarskich i aktywne zarybianie akwenów wodnych. Mieszkańcy Białego Boru wskazali, że szczególnie atrakcyjne dla turystów są i mogą być znajdujące się na terenie gminy jeziora. Wśród silnych stron w odniesieniu do wędkarstwa strategia wskazuje walory przyrodnicze (jeziora, czysta woda), dobre warunki do uprawiania wędkarstwa (jeziora Grębosz, Gręboszynek, Racze), działalność gospodarstw agroturystycznych. Z kolei słabą stroną w tym zakresie jest brak ryb w jeziorach.

Dwie gminy wśród analizowanych miały strategię rozwoju turystyki wcześniej, ale w obecnej sytuacji są one nieaktualne i jak na razie nie podjęto działań w zakresie opracowania nowych wersji w przypadku obu gmin (Barwice, Borne Sulinowo). Nie oznacza to, że nie można dokonać analizy pod kątem rozwoju turystyki wędkarskiej lub innej wodnej. Strategia rozwoju turystyki gminy Borne Sulinowo wskazuje, że do naturalnych atrakcji turystycznych zaliczyć należy 55 pięknie położonych jezior, wśród których najważniejsze to jeziora: Pile, Komorze, Lubicko Wielkie, Ciemino i Śmiadowo. Wskazano, że tereny wokół tych jezior posiadają warunki najbardziej korzystne do rozwoju różnych form turystyki związanych z pobytem nad wodą oraz uprawianiem sportów wodnych. Wskazano wykorzystanie możliwości związanych z dużą ilością zbiorników wodnych poprzez budowę infrastruktury nadbrzeżnej (pomosty, mola, stanice wodne, przystanie). Strategia wskazuje również na potrzebę rozwoju różnych 
form turystyki kwalifikowanej oraz zarybianie jezior. W strategii brak wyraźnego odniesienia do turystyki wędkarskiej i produktów z nią związanych, za wyjątkiem eventu: Poligon Wędkarski Borne Sulinowo - ogólnopolskie zawody wędkarskie jako impreza cykliczna. Strategia rozwoju turystyki gminy Barwice wskazuje, że obszar gminy jest stosunkowo ubogi, jeśli chodzi o występowanie akwenów jeziornych. Dużym atutem jest przepływająca przez gminę rzeka Parsęta i ona jest wskazywana jako podstawa do rozwoju turystyki wodnej. Strategia stawia jednak na możliwości rozwoju turystyki specjalistycznej, a w szczególności turystyki wędkarskiej. Zawody wędkarskie są wskazywane jako jedno z narzędzi na wydłużanie sezonu turystycznego.

Jednakże w większości gmin i w powiecie funkcjonuje dokument strategiczny (najczęściej jako strategia rozwoju gminy, w przypadku powiatu - strategia rozwoju powiatu, w przypadki Lokalnej Grupy Działania - lokalna strategia rozwoju), w ramach którego wskazana jest turystyka jako ważne działanie rozwojowe bazujące na walorach naturalnych i antropogenicznych. Walory te zazwyczaj są określane jako podstawa działań proturystycznych i kierunek rozwoju gospodarczego. Turystyka widoczna jest zarówno w zinwentaryzowanych zasobach naturalnych, jak i poszczególnych wizjach i misjach. Gmina Szczecinek podkreśla duże znaczenie walorów środowiska naturalnego. Stawia na rozwój oferty aktywnych form wypoczynku, rozszerzanie ofert imprez, dbanie o czystość jezior. Brak jednoznacznego odniesienia do turystyki wędkarskiej. Gmina Borne Sulinowo w strategii rozwoju wskazuje, że gmina posiada zasoby do rozwoju różnych form turystyki kwalifikowanej, w tym kajakowej, wodnej. Jeśli chodzi o turystykę wędkarską, to strategia wskazuje na potrzebę utrzymania imprezy wędkarskiej - Podlodowe Zawody Wędkarskie. Jeden z celów operacyjnych wskazuje na potrzebę tworzenia markowych produktów turystycznych w oparciu o istniejące zbiorniki wodne poprzez współzarządzanie gospodarką rybacką na jeziorach Pile, Długie i na rzece Piława. Gmina Biały Bór podkreśla, że obszar gminy jest atrakcyjny i urozmaicony pod względem krajobrazowym i sprzyja rozwojowi różnych form turystyki aktywnej, w tym wodnej. Strategia rozwoju wskazuje na potrzebę poprawy jakości infrastruktury turystycznej, w tym wodnej. Ważny staje się również problem jakości wód w jeziorze Bielsko oraz zwiększenie jego dostępności dla wędkarzy, przede wszystkim poprzez montaż pomostów wędkarskich. Strategia gminy Grzmiąca wskazuje, że niemal cały obszar gminy znajduje się w zlewni rzeki Parsęty. Natomiast podkreśla się fakt całkowitego braku jezior. Rozwój turystyki wodnej i wędkarskiej jest spowodowany brakiem większych akwenów wodnych. Wędkarstwo może się rozwijać wyłącznie w oparciu o rzekę Parsętę wraz z jej dopływami. Wskazuje się na potrzebę zagospodarowania terenu wokół jeziora Baczyno. Lokalna strategia rozwoju LGD Pojezierze Razem wskazuje na potrzebę tworzenia całorocznych produktów turystycznych, również w oparciu o zasoby wodne. LGD wskazuje, że obszar jej działania ma potencjał związany z rozwojem oferty opartej na rybach. W lipcu 2013 roku na listę produktów tradycyjnych prowadzoną przez ministra rolnictwa i rozwoju wsi wpisana została sielawa wędzona z Pojezierza Drawskiego jako pierwszy przysmak rybny z tego obszaru. Wniosek o jej wpis złożyła Lokalna Grupa Rybacka Partnerstwo Drawy w Szczecinku. Źródłem tego przysmaku są dwa jeziora sielawowe w obrębie gminy Borne Sulinowo: Pile oraz Komorze. Powiat szczecinecki wskazuje, że jest krainą setek jezior, pięknych, grzybnych lasów i malowniczych krajobrazów. Są to znakomite tereny dla turystów amatorów wycieczek pieszych i rowerowych, spływów kajakowych, biwaków, a także dla żeglarzy, wędkarzy, grzybiarzy. 


\section{ZOGNISKOWANE WYWIADY GRUPOWE JAKO ŹRÓDŁO WIEDZY O MOŻLIWOŚCIACH ROZWOJU TURYSTYKI WĘDKARSKIEJ NA BADANYM OBSZARZE}

Badanie to przeprowadzone zostało w 2019 roku i dotyczyło uzyskania opinii przedstawicieli administracji publicznej, przedsiębiorców turystycznych i organizacji pozarządowych na temat uwarunkowań rozwoju turystyki wędkarskiej na terenie powiatu szczecineckiego, opracowane na podstawie analizy zogniskowanych wywiadów grupowych. Po ich przeprowadzeniu uzyskano następujące wnioski:

- Walory dotyczące turystyki wędkarskiej powiatu szczecineckiego w ocenie respondentów są bardzo duże, szczególnie ze względu na przyrodnicze, w tym ichtiologiczne zróżnicowanie akwenów oraz wód płynących.

- Rybostan został oceniony na średnim poziomie, m.in. ze względu na nie do końca transparentną politykę zarybiania poszczególnych akwenów przez odpowiedzialne za to podmioty.

- Wskazano, że najlepiej zagospodarowane pod względem turystyczno-wędkarskim są miasto Szczecinek i gmina Borne Sulinowo. Pozostała część powiatu ma bardzo skromną bazę turystyczną, zarówno hotelową (tylko gospodarstwa agroturystyczne), jak i specjalistyczną dla wędkarzy. Nawet w Szczecinku w trakcie wysokiego sezonu turystycznego oraz w czasie organizowania dużych imprez wędkarskich występują problemy z miejscami noclegowymi.

- Ważnym problemem wymagającym pilnego rozwiązania są trudności z dojazdem do zbiorników wodnych ze względu na ograniczenia w korzystaniu z dróg dojazdowych na terenach administrowanych przez Lasy Państwowe oraz zbyt mała liczba odpowiednich miejsc do wodowania łodzi.

- Uczestnicy badania stwierdzili, że jedną z najważniejszych barier rozwoju turystyki wędkarskiej w powiecie szczecineckim jest niedostatek informacji turystycznych i specjalistycznych dla wędkarzy, zarówno w terenie, jak i w internecie.

- Dużym utrudnieniem dla wędkarzy przyjeżdżających do powiatu szczecineckiego jest kwestia nabywania zezwoleń na połów ryb. Przyczyną są: niedostateczna ilość punktów sprzedaży w terenie, nieodpowiednie godziny ich działania, brak informacji o ich lokalizacji, brak dostępnych w internecie i na miejscu informacji o podmiocie odpowiedzialnym za gospodarkę rybacką na danym terenie.

- Zwrócono także uwagę, że niezbędne jest dostosowanie oferty turystycznej do dwóch typów turystów wędkarzy: zazwyczaj przyjeżdżającego indywidualnie profesjonalisty oraz amatora, któremu towarzyszy rodzina.

- Stwierdzono, że istnieją dwa rodzaje zagrożeń, które wpływają negatywnie na rozwój turystyki wędkarskiej. Pierwszym z nich jest rosnąca populacja kormoranów, a drugim kłusownictwo.

\section{PODSUMOWANIE}

Na podstawie analizy dokumentów strategicznych, materiałów pozyskanych z gmin i powiatu szczecineckiego oraz badań empirycznych (wywiadów zogniskowanych) zidentyfikowano najważniejsze elementy, które wyróżniają powiat szczecinecki jako obszar wędkarski: 
1. Duża liczba naturalnych zbiorników wodnych: jezior i rzek o bardzo urozmaiconej linii brzegowej, położonych zarówno z dala od dużych skupisk ludzkich, jak i w ich pobliżu (jeziora miejskie Trzesiecko, Pile).

2. Urozmaicony krajobraz polodowcowy oraz występowanie dużych obszarów leśnych.

3. Niski poziom zanieczyszczenia wód i powietrza.

4. Niski stopień przekształcenia antropogenicznego elementów środowiska przyrodniczego.

5. Występowanie na terenie powiatu obszarów chronionych (takich jak rezerwaty przyrody, obszary Natura 2000).

6. Różnorodność i wysoka jakość rybostanu w akwenach i ciekach wodnych.

7. Dość wysoka świadomość potrzeb turystów wędkarzy i gościnność gospodarzy kwater agroturystycznych.

Hipoteza badawcza o treści: posiadane przez analizowany powiat i jego poszczególne gminy wodne zasoby endogeniczne mogą stanowić podstawę do tworzenia jeszcze bardziej specjalistycznych produktów turystycznych i kreowania na ich podstawie lokalnej strategii rozwoju - została zweryfikowana pozytywnie. Wskazane w artykule wodne zasoby endogeniczne są niezbędne do kreowania lokalnego powiatowego produktu turystyki wędkarskiej. Dalszym działaniem powinno być opracowanie lokalnej strategii rozwoju i promocji turystyki wędkarskiej.

W celu rozwoju zintegrowanego produktu turystyki wędkarskiej na terenie powiatu szczecineckiego należy zatem podjąć następujące działania, które pozwolą poprawić wizerunek powiatu w tym zakresie i stworzyć atrakcyjną ofertę dla turystów wędkarskich:

- Stworzenie wspólnej platformy współpracy właścicieli głównych zbiorników wędkarskich w powiecie szczecineckim: Polski Związek Wędkarski, dzierżawcy jezior, poszczególne gminy i miasta oraz wędkarze.

- Podjęcie wspólnych działań w zakresie informacji i promocji obszarów wędkarskich, uruchomienie wspólnych punktów sprzedaży pozwoleń wędkarskich, ujednolicenie opłat za wędkowanie i wprowadzenie dogodnych form płatności (przez internet, karta kredytowa).

- Poprawa stanu i rozwój infrastruktury - pomostów, kładek (w tym odpinanych) oraz systemu usług - wypożyczalni sprzętu wędkarskiego, łodzi itp.

- Oznakowanie kładek, pomostów i miejsc do spuszczania łodzi.

- Stworzenie modelu i standaryzacja kwater/ośrodków wędkarskich.

- Szkolenia/przygotowanie przewodników/pomocników wędkarskich.

- Stworzenie łowisk typu put and take („szczecineckie łowiska” - budowa sieci małych baz wędkarskich, m.in. małe przystanie oraz system wypożyczalni sprzętu wędkarskiego).

- Przeprowadzenie szerokiej kampanii promocyjnej turystyki wędkarskiej w powiecie szczecineckim.

- „Udogodnienia - na łowiskach” - poprawa stanu i rozwój infrastruktury - pomostów, kładek oraz systemu usług: wypożyczalni łodzi itp.

- Specjalne programy wsparcia rozwoju potencjału łowisk wędkarskich.

- Opracowanie pakietów weekendowych i edukacyjnych w zakresie wędkarstwa, hippiki, myślistwa. 
Obecnie w powiecie szczecineckim nie ma zorganizowanego systemu sprzedaży ofert turystyki wędkarskiej. Praktycznie turystyka wędkarska jest elementem towarzyszącym ofertom wypoczynku w obiektach turystycznych położonych nad jeziorami bądź rzekami, ale nie stanowi samodzielnej zintegrowanej oferty zarówno w skali powiatu, jak i pojedynczych obiektów turystycznych. Brakuje typowych obiektów/ kwater przystosowanych do organizacji profesjonalnej turystyki wędkarskiej z całym pakietem wyposażenia i usług oferowanych wędkarzom, jak ma to miejsce w innych europejskich regionach wędkarskich.

Propozycje przedsięwzięć w zakresie rozwoju wędkarskiego produktu turystycznego w powiecie szczecineckim:

1. Wybór i kategoryzacja kwater agroturystycznych położonych w pobliżu akwenów wodnych, które chcą specjalizować się w turystyce wędkarskiej.

2. Uzgodnienie zasad współpracy z dzierżawcami wód (jezior i rzek), nad którymi zlokalizowane są kwatery wędkarskie.

3. Uzgodnienie z kwaterodawcami i dzierżawcami zasad polityki cenowej i poziomu cen stosowanego w ramach produktu.

4. Zawarcie stosownych umów z kwaterodawcami i dzierżawcami o współpracy w zakresie promocji i sprzedaży oferty turystyki wędkarskiej.

5. Nawiązanie współpracy ze sklepami wędkarskimi, wypożyczalniami i punktami informacji turystycznej w sprawie promocji produktu turystycznego. Stworzenie listy podmiotów, które będą uczestniczyły w takiej promocji.

6. Opracowanie marki i logo produktu oraz katalogu ich zastosowania.

7. Przygotowanie szczegółowych opisów akwenów wodnych, które będą objęte promocją produktu turystycznego.

8. Przygotowanie szczegółowych opisów i oferty kwater wędkarskich w zależności od ich specyfiki w formie pakietów produktowych.

9. Szkolenia/przygotowanie przewodników/pomocników wędkarskich oraz właścicieli/pracowników kwater wędkarskich.

10. Opracowanie planów oznakowania dróg dojazdowych, brzegów akwenów i kwater wędkarskich.

11. Zbudowanie portalu turystyki wędkarskiej dla całego powiatu szczecineckiego wraz z systemem rezerwacji.

12. Przygotowanie informacji o produkcie dla innych portali wędkarskich.

13. Przygotowanie reklamy portalu turystyki wędkarskiej w powiecie szczecineckim w prasie wędkarskiej.

14. Przygotowanie ulotek informacyjnych o produkcie do wykorzystania w promocji lokalnej i na imprezach targów turystycznych i wędkarskich.

15. Wykonanie znaków i tablic informacyjnych.

16. Oznakowanie kwater wędkarskich, dróg dojazdowych oraz brzegów rzek i jezior.

17. Przygotowanie i cykliczna emisja programu promocyjnego w popularnym telewizyjnym programie wędkarskim.

18. Organizacja cykliczna study tour dla dziennikarzy wędkarskich.

19. Organizacja cyklicznych zawodów wędkarskich.

Rozwój i planowanie turystyki na poziomie lokalnym, zwłaszcza gminnym, wymaga od lokalnych władz myślenia i działania nieoperacyjnego, tj. nie z jednego sezonu turystycznego na kolejny sezon, ale w dużej mierze strategicznego, czego przykładem 
powinien być dobrze opracowany plan rozwojowy gminy lub też poświęcona turystyce strategia (Szostak, 2019).

Proces planowania długoletniego w obszarze rozwoju lokalnej usługowej gospodarki turystycznej opartej na posiadanych zasobach endogenicznych pozwala na wskazanie wielu praktycznych korzyści i efektów dla poszczególnych gmin i powiatów, a mianowicie na:

- identyfikację podstawowych oraz kluczowych problemów rozwojowych lokalnych gospodarek i społeczności;

- identyfikację strategicznych turystycznych potencjałów rozwojowych danej gminy;

- dokładną inwentaryzację turystycznego potencjału endogenicznego gminy (np. jakie konkretnie zasoby wodne posiada dany obszar i do czego mogą służyć);

- identyfikację kluczowych turystycznych szans i zagrożeń rozwojowych;

- skoordynowanie i ukierunkowanie działań wszystkich uczestników procesów rozwojowych gminy (władz, społeczności i lokalnego biznesu) wokół powyższych uwarunkowań i wyznaczonych celów do realizacji;

- wskazanie narzędzi niezbędnych do realizacji przedsięwzięć turystycznych uznanych za najważniejsze dla rozwoju lokalnego;

- koordynację w czasie i przestrzeni owych przedsięwzięć poprzez identyfikację głównych centrów rozwojowych i przypisanie im czasowych ram realizacji;

- integrację tej dominującej części społeczności lokalnej wokół wizji i szczegółowych koncepcji rozwoju lokalnego oraz wspólnych działań na jej rzecz (Sztando, 2015: 106-107).

Podsumowując, należy stwierdzić, że najlepszym sposobem wdrożenia nowego produktu turystycznego jest opracowywanie i wdrażanie lokalnej usługowej strategii rozwoju opartej na turystyce wodnej, w tym wędkarskiej. Powinno to przyczynić się do wskazania obszarów działalności turystycznej zapewniających największe lokalne korzyści społeczno-gospodarcze, zrozumienia, dlaczego różne inicjatywy w różnych obszarach działalności turystycznej przyniosły sukces rynkowy lub niepowodzenie, wskazania, jakich kwalifikacji i zasobów endogenicznych brakuje na lokalnym rynku turystycznym lub są one niewystarczające, wskazania grup docelowych turystów, o których najbardziej trzeba się troszczyć i którzy będą beneficjentami rozwoju lokalnego turystycznego produktu usługowego, tworzenia lokalnych produktów turystycznych na bazie posiadanego potencjału endogenicznego (Szostak, Zalewski 2017).

\section{Literatura \\ References}

Duda, M., Duda, T., Śledziński, R. (2014). Kanon krajoznawczy województwa zachodniopomorskiego. Szczecin: AFR.

Głąbiński, Z., Duda, T., Szostak, D. (2017). Strategia rozwoju turystyki dla gminy Karlino do 2025 roku. Karlino.

Głąbiński, Z., Szostak, D., Zalewski, T. (2016). Strategia rozwoju turystyki na poziomie lokalnym. Przykład powiatu gryfińskiego. Warszawa: CeDeWu.

Główny Urząd Statystyczny (GUS) (2019, 18 grudnia). Pozyskano z https://szczecin.stat.gov.pl/ vademecum/vademecum_zachodniopomorskie/portrety_powiatow/powiat_szczecinecki. pdf

Gołembski, G., (2002). Metody stymulowania turystyki w ujęciu przestrzennym. Wydawnictwo AE w Poznaniu, Poznań. 
Grabowska, A. (2016). Lokalna gospodarka turystyczna a rozwój regionów. Katowice: Uniwersytet Ekonomiczny. Pozyskano z https://www.ue.katowice.pl/fileadmin/_migrated/content_ uploads/5_A.Grabowska_Lokalna_gospodarka_turystyczna_a_rozwoj.pdf

Kaczmarek, J., Stasiak, A., Włodarczyk, B. (2005). Produkt turystyczny. Warszawa: Polskie Wydawnictwo Ekonomiczne.

Kaganek, K., (2015). Różnorodność pojęć w zakresie aktywnego uprawiania turystyki. W: A. Stasiak, J. Śledzińska, B. Włodarczyk (red.). Wczoraj, dziś i jutro turystyki aktywnej i specjalistycznej. Warszawa: Polskie Towarzystwo Turystyczno-Krajoznawcze.

Panasiuk, A. (2006). Ekonomika turystyki. Warszawa: Wydawnictwo Naukowe PWN.

Rapacz, A., Jaremen, D.E. (2009). Oddziaływanie samorządu lokalnego na rozwój turystyki i branży turystycznej w wybranych gminach powiatu jeleniogórskiego. Prace Naukowe Uniwersytetu Ekonomicznego we Wrocławiu, 46, 303-314.

Sidorkiewicz, M. (2009). Procedura konstruowania strategii rozwoju turystyki. W: B. Meyer, D. Milewski (red.). Strategia rozwoju turystyki w regionie. Warszawa: Wydawnictwo Naukowe PWN.

Skowyrski, J. (2010). Powiat szczecinecki. Zeszyt krajoznawczo-metodyczny. Szczecin: FTR.

Spławik i Grunt - blog (2019, 18 grudnia). Turystyka wędkarska w Polsce. Pozyskano z http:// splawikigrunt.pl/blog/turystyka-wedkarska-w-polsce

Szostak, D. (2019). Planowanie rozwoju lokalnego jako samorządowe narzędzie kształtowania funkcji usługowej gminy Moryń. Prace Komisji Geografii Przemysłu Polskiego Towarzystwa Geograficznego, 33(2), 95-110.

Szostak, D., Zalewski, T. (2017). Tworzenie lokalnych produktów turystycznych na bazie potencjału endogenicznego na przykładzie gminy Moryń. Roczniki Chojeńskie, 9.

Sztando, A. (2015). Współczesne bariery zarządzania strategicznego rozwojem lokalnym w Polsce. Nauki o Zarzq̨dzaniu, 4(25), 105-124.

Daniel Szostak, dr, Uniwersytet Szczeciński, Instytut Gospodarki Przestrzennej i Geografii Społeczno-Ekonomicznej. Jego zainteresowania badawcze: ekonomika turystyki, strategie rozwoju turystyki, hotelarstwo, planowanie w turystyce, finansowanie turystyki, rozwój lokalny i regionalny, turystyka w gospodarce przestrzennej, zakładanie i prowadzenie działalności gospodarczej, funkcjonowanie przedsiębiorstwa turystycznego, zarządzanie ludźmi, komunikacja interpersonalna, skuteczne metody poszukiwania pracy, aktywność proprzedsiębiorcza studentów oraz osób bezrobotnych, praca zespołowa, marketing turystyczny i terytorialny.

Daniel Szostak, PhD, University of Szczecin, Institute of Spatial Management and Socio-Economic Geography. His research interests: tourism economics, tourism development strategies, hotel management, tourism planning, tourism financing, local and regional development, tourism in the spatial economy, establishing and running a business, tourism company operation, people management, interpersonal communication, effective job search methods, entrepreneurial activity of students and the unemployed, team working, tourism and territorial marketing.

ORCID: 0000-0002-2912-2672

\section{Adres/address}

Uniwersytet Szczeciński

Instytut Gospodarki Przestrzennej i Geografii Społeczno-Ekonomicznej

ul. Mickiewicza 18, 70-383 Szczecin, Polska

e-mail: daniel.szostak@usz.edu.pl 